\title{
ANALYTICAL DIAGNOSING OF MILNACIPRAN POISONINGS
}

\author{
S.V.Baiurka, S.A.Karpushyna, V.P.Moroz
}

\author{
National University of Pharmacy \\ Key words: chemico-toxicological analysis; milnacipran; isolation from the biological material; \\ TLC-screening; high pressure liquid chromatography
}

\begin{abstract}
The method of milnacipran isolation with chloroform from the dehydrated biological material with subsequent extraction purification in the $n$-hexane-acetonitrile solvent system has been developed. The method developed has allowed to isolate $47 \pm 5 \%$ of the antidepressant. The TLC-screening method of a number of antidepressants has been developed using four mobile phases with a low correlation and the sequential scheme of visualization by a set of chromogenic reagents. It has allowed to separate milnacipran, venlafaxine, amitriptyline, fluoxetine and sertraline. As differentiating reagents the Liebermann's reagent and the Mandelin's reagent in modification consisting in sequential treatment of the sample by the Mandelin's reagent and formaldehyde vapours have been suggested. The methods of identification and quantitative determination of milnacipran in the biological material after the TLC purification using HPLC with multiwave UV-spectrophotometric detection have been developed. The calibration curve of the dependence of the peak area on the concentration was described by the following equation: $Y=5.14 \cdot 10^{-5} \mathrm{X}$; linearity was within the concentration range of $24.2-500 \mu \mathrm{g} / \mathrm{ml}$; $L O D$ and $L O Q$ were 8.0 and $24.2 \mu \mathrm{g} / \mathrm{ml}$ (at $262 \mathrm{~nm}$ ), respectively. The results obtained can be used in forensic toxicology for diagnosing milnacipran poisonings.
\end{abstract}

$\mathrm{M}$ ilnacipran - (1R,2S)-rel2-(Aminomethyl) $-\mathrm{N}, \mathrm{N}-$ diethyl-1-phenylcyclopropanecarboxamide is a novel third-generation thymoleptic. Its pharmacological effect is due to the dual action, it is a selective serotonin and norepinephrine reuptake inhibitor (SNRI). Milnacipran is used for the treatment of moderate and severe endogenous depression [3]. Fatal intoxications associated with milnacipran overdoses and co-administration of fluoxetine and sertraline in therapeutic doses [8], as well as ethanol [10] have been reported, in these cases peripheral blood concentrations of milnacipran are $21.5 \mathrm{mg} / \mathrm{l}$ and $3.15 \mu \mathrm{g} / \mathrm{ml}$, respectively.

Bioanalytical methods for analysis of milnacipran in the blood and plasma using high pressure liquid chromatography with UV spectrophotometric [7], diode array [12] and MS- [5] detection have been developed. Methods of analysing the biological material for the presence of milnacipran have not been developed. The general isolation methods appeared to be ineffective for a number of antidepressants, in particular for ami- triptyline, fluoxetine and sertraline $[1,2]$, due to the lipophilic properties of these substances [6]. In this regard, the practical interest is the study of the efficiency of milnacipran isolation $(\mathrm{Vd}=5.5 \mathrm{l} / \mathrm{kg}$ [6]) from the biological material with chloroform as a lipophilic solvent with subsequent extraction purification in the $n$-hexane-acetonitrile solvent system [4]. Therefore, the aim of this study was to determine the optimal conditions for milnacipran isolation from the biological material, develop the TLCscreening scheme for the group of antidepressants, which can be co-administrated with milnacipran, as well as the methods of identification and quantitative determination for milnacipran in the biological material by HPLC with multiwave UV-spectrophotometric detection.

\section{Materials and Methods}

The method of milnacipran isolation with chloroform with subsequent extraction purification in the n-hexane-acetonitrile solvent system. Add $1 \mathrm{ml}$ of the aqueous solution containing $574 \mathrm{mg}$ of milnacipran hydrochloride (corres-

S.V.Baiurka - Candidate of Pharmacy, associate professor of the Department of Toxicological Chemistry of the National University of Pharmacy (Kharkiv) ponding to $500 \mathrm{mg}$ of the milnacipran base) to the powdered biological sample $(5 \mathrm{~g}$ of the liver tissue) and allow to stand for $24 \mathrm{~h}$. Simultaneously perform the blank experiment.

Isolation of milnacipran from the liver with chloroform was carried by the method given in the work [7].

The method of Thin Layer Chromatography. Two types of chromatographic plates - Merk (Silica gel $60 \mathrm{~F} 254,10 \times 20 \mathrm{~cm}$ in size) and Sorbfil (PTLC-P-A) $(10 \times 10 \mathrm{~cm}$ in size) were used for thin-layer chromatographic studies.

Evaporate $10-30 \mathrm{ml}$ aliquots of the final chloroform extract obtained from the tissue spiked with milnacipran and extracts from the blank tissue (drug-free) to the minimum volume $(\sim 0.05 \mathrm{ml})$ and spot as a band onto the start line. Next to it spot $10 \mathrm{ml}$ of the standard solution of milnacipran in methanol $(1 \mathrm{mg} / \mathrm{ml})$. At first develop the chromatograms in chloroform to separate the drug from endogenous impurities, then use four mobile phases (listed below).

Thin-layer chromatographic studies were performed as described in the work $[1,2,4]$. The antidepressant was detected on the plate with the chromogenic reagents pre- 
The results of antidepressant visualization in TLC-screening

\begin{tabular}{|c|c|c|c|c|c|}
\hline \multirow[b]{2}{*}{ Antidepressant } & \multicolumn{5}{|c|}{ Reagent (colour and sensitivity, $\mu \mathrm{g}$ per a sample) } \\
\hline & $\begin{array}{l}\text { Dragendorff's } \\
\text { reagent by Munier }\end{array}$ & $\begin{array}{c}\text { acidified } \\
\text { iodoplatinate }\end{array}$ & $\begin{array}{l}\text { Liebermann's } \\
\text { reagent }\end{array}$ & $\begin{array}{l}\text { Mandelin's } \\
\text { reagent }\end{array}$ & $\begin{array}{c}\text { Mandelin's } \\
\text { reagent + } \\
\text { formaldehyde }\end{array}$ \\
\hline Milnacipran & orange $(5.0)$ & blue (1.0) & $\begin{array}{l}\text { yellow } \rightarrow \text { orange } \\
(5.0)\end{array}$ & - & - \\
\hline Venlafaxine & orange (3.0) & blue-violet (2.0) & $\begin{array}{l}\text { brown } \rightarrow \text { cherry } \\
\rightarrow \text { red }(5.0)\end{array}$ & $\begin{array}{l}\text { brown } \rightarrow \text { cherry } \\
\rightarrow \text { blue } \rightarrow \text { green } \\
(4.0)\end{array}$ & $\begin{array}{l}\text { light } \\
\text { blue (5.0) }\end{array}$ \\
\hline Amitriptyline & orange (2.0) & blue-violet (0.2) & $\begin{array}{l}\text { yellowish- } \\
\text { brown (3.0) }\end{array}$ & brown (0.5) & brown (0.5) \\
\hline Fluoxetine & orange (1.0) & blue-violet (0.5) & \begin{tabular}{|l|} 
brown \\
$(3.0)$
\end{tabular} & blue (3.0) & green (3.0) \\
\hline Sertraline & orange (1.0) & violet (1.0) & $\begin{array}{l}\text { violet } \rightarrow \text { brown } \\
\rightarrow \text { discoloration } \\
(2.0)\end{array}$ & - & - \\
\hline
\end{tabular}

Table 2

\section{Chromogenic reagents for the final stage of the antidepressant visualization in TLC-screening}

\begin{tabular}{|l|l|l|l|}
\hline Antidepressant & \multicolumn{3}{|c|}{ Reagent (colour and sensitivity, $\mu$ g per a sample) } \\
\hline Milnacipran & ninhydrin (pink-violet, 4.0) & $\begin{array}{l}\text { mercury sulphate saturated } \\
\text { solution (blue, 6.0) }\end{array}$ & Van Urk's (yellow, 3.0) \\
\hline Venlafaxine & Froehde (greenish $\rightarrow$ violet (on the edge), 8.0) \\
\hline Amitriptyline & concentrated sulphuric acid (orange, 0.2) & Froehde (brick-red $\rightarrow$ green, 5.0) \\
\hline Fluoxetine & ninhydrin (orange, 5.0) & Froehde (blue, 4.0) & $\begin{array}{l}\text { Froehde } \\
\text { (brownish-green, 5.0) }\end{array}$ \\
\hline Sertraline & $\begin{array}{l}\text { potassium permanganate solution } \\
\text { (blue-violet, 5.0) }\end{array}$ & Van Urk's (yellow, 5.0) \\
\hline
\end{tabular}

sented in Tables 1, 2. Elute milnacipran from the chromatogram band untreated by the location reagents with methanol. Evaporate the eluate, and reconstitute the residue $1 \mathrm{ml}$ of methanol.

The method of HPLC. The HPLC study was performed using a "MiLiChrome A-02" microcolumn high pressure liquid chromatograph with a multiwave UV-spectrophometric detector by the method presented in the work [4]. The injected volume was $10 \mu \mathrm{l}$. Quantitative determination of milnacipran in eluates from chromatograms was carried out at the wavelength of $262 \mathrm{~nm}$.

\section{Results and Discussion}

According to the epidemiological studies [9] the most poisonings with novel antidepressants are combined. The scheme of mil- nacipran detection by thin layer chromatography screening method in the presence of a number of antidepressants from different groups such as venlafaxine (SNRI), amitriptyline (TCA), sertraline and fluoxetine (SSRI) has been developed.

The simultaneous use of four mobile phases (MP) with a high distributive power in relation to drugs under study and the lowest correlation between them was proposed. They are ethyl acetate methanol - $25 \%$ ammonium hydroxide solution (85:10:5) (MP 1), methanol - 25\% ammonium hydroxide solution (100:1.5) (MP 2), cyclohexane - toluene - diethylamine (75:15:10) (MP 3), and toluene - acetone - ethanol - 25\% ammonium hydroxide solution (45:45:7.5:2.5) (MP 4). The Rf values of antidepressants in the mo- bile phases selected on two types of the chromatographic plates (Merk and Sorbfil) are shown in Table 3. The Dragendorff's reagent modified by Munier and acidified iodoplatinate solution were the most sensitive common reagents for detection of the substances studied. As differentiating reagents the Liebermann's reagent and the Mandelin's reagent in modification consisting in sequential treatment of the sample by the Mandelin's reagent and formaldehyde vapours were suggested (Table 1). Using a particular set of additional chromogenic reagents (Table 2) it was proposed to use four reagents, and it was sufficient for reliable identification of toxic substances according to the TIAFT recommendations [7] for the final stage of visualization. The degree of milnacipran elution with methanol from 
The Rf values of antidepressants in TLC-screening systems

\begin{tabular}{|l|c|c|c|c|c|c|c|c|}
\hline \multirow{3}{*}{ Antidepressant } & \multicolumn{9}{c|}{ Mobile phase $\left(\mathrm{N}_{\mathrm{o}}\right)$} \\
\cline { 2 - 11 } & \multicolumn{2}{|c|}{1} & \multicolumn{2}{|c|}{2} & \multicolumn{2}{c|}{3} & \multicolumn{2}{c|}{4} \\
\cline { 2 - 11 } & Merk & Sorbfil & Merk & Sorbfil & Merk & Sorbfil & Merk & Sorbfil \\
\hline Milnacipran & 0.31 & 0.53 & 0.28 & 0.37 & 0.05 & 0.09 & 0.42 & 0.47 \\
\hline Venlafaxine & 0.84 & 0.90 & 0.65 & 0.66 & 0.57 & 0.70 & 0.71 & 0.92 \\
\hline Amitriptyline & 0.91 & 0.92 & 0.51 & 0.61 & 0.88 & 0.85 & 0.67 & 0.92 \\
\hline Fluoxetine & 0.90 & 0.95 & 0.78 & 0.72 & 0.30 & 0.28 & 0.40 & 0.92 \\
\hline Sertraline & 0.54 & 0.90 & 0.67 & 0.68 & 0.64 & 0.88 & 0.75 & 0.71 \\
\hline
\end{tabular}

Table 4

\section{The results of HPLC determination of milnacipran isolated from the liver with chloroform followed by purification in the $n$-hexane-acetonitrile system}

\begin{tabular}{|c|c|c|c|c|c|}
\hline \multirow{2}{*}{$\begin{array}{c}\text { Amount of } \\
\text { milnacipran added to } \\
5 \mathrm{~g} \text { of the liver, } \mu \mathrm{g}\end{array}$} & $\begin{array}{c}\text { Amount of } \\
\text { milnacipran } \\
\text { extracted }(\overline{\mathrm{X}}, \%)\end{array}$ & $\mathrm{S}$ & $\mathrm{S}_{\overline{\mathrm{X}}}$ & \multicolumn{4}{|c|}{ Metrological characteristics } \\
\cline { 3 - 6 } & 47 & 3.8 & 1.7 & $5 \overline{\mathrm{X}}$ & $\varepsilon, \%$ \\
\hline 500 & 47 & $\mathrm{P}=0.95 \%, v=4)$ & 10 \\
\hline
\end{tabular}

the chromatographic plates was $97.8 \pm 1.0 \%$.

Identification of milnacipran in the eluates by HPLC was carried out by the retention time and the absorbance ratios $\left(R=S_{\lambda} / S_{210}\right)$, they were $17.00 \pm 0.06 \mathrm{~min}(\mathrm{n}=5$, $\mathrm{RSD}=0.15 \%, \varepsilon=0.37 \%$ ) and $0.811 \pm$ $\pm 0.007 ; 0.291 \pm 0.004 ; 0.030 \pm 0.002$; $0.012 \pm 0.002 ; 0.014 \pm 0.002 ; 0.0021 \pm$ $\pm 0.0002 ; 0.0014 \pm 0.0003$, respectively. Quantitative determination was performed using the calibration curve of the dependence of the peak area on the concentration at the wavelength of $262 \mathrm{~nm}$. After verifying the significance of the intercept in the linear regression equation it was concluded about the possibility of transition to the equation in the form of: $\mathrm{Y}=5.14 \cdot 10^{-5} \mathrm{X}$ (Table 4 ). The method showed linearity in the range of 24.2-500 mg/mL. The LOD and
LOQ values were calculated based on the parameters of the calibration curve; they were $8.0 \mu \mathrm{g} / \mathrm{ml}$ and $24.2 \mu \mathrm{g} / \mathrm{ml}$, respectively. Accuracy and precision of the method developed were $101.8 \%$ (RSD= $=1.4 \%$ ) at the low concentration level, $100.8 \%$ and $100.5 \%$ (RSD= $=1.0 \%$ ) at the middle and high concentration levels, respectively. Therefore, they satisfy the requirements for the methods used in forensic toxicology [11].

The method of milnacipran isolation with chloroform was quite efficient and allowed isolating $47 \pm 5 \%$ of the antidepressant studied (Table 4). The results obtained can be used in forensic toxicology for diagnosing milnacipran poisonings.

\section{CONCLUSIONS}

1. The method of milnacipran isolation with chloroform from the biological material dehydrated by triturating with anhydrous sodium sulphate with subsequent extraction purification in the $n$-hexaneacetonitrile solvent system has been developed. The method developed has allowed to isolate $47 \pm 5 \%$ of the medicine.

2. The TLC-screening method of a number of antidepressants has been developed using four mobile phases with low correlation and the sequential scheme of visualization by chromogenic reagents. It has allowed to separate milnacipran, venlafaxine, amitriptyline, fluoxetine and sertraline.

3. The sensitive and specific methods of identification and quantitative determination of milnacipran in the biological material by HPLC with multiwave UV-spectrophotometric detection have been developed.

\section{REFERENCES}

1. Баюрка С.В., Бондар В.С., Карпушина С.А. // Вісник фармації. - 2009. - №3 (59). - С. 23-26.

2. Баюрка С.В., Карпушина С.А., Мороз В. П. // Фармация. - 2015. - №2. - С. 7-9.

3. Фурсов Б.Б. // Психические расстройства в общей медищине. - 2009. - №2. - С. 63-65.

4. Baiurka S., Karpushina S. // J. Chem. Pharm. Res. - 2013. - Vol. 5 (12). - P. 1110-1120.

5. Castaing N., Titier K., Receveur-Daurel M. et al. // J. Anal. Toxicol. - 2007. - Vol. 31 (6). - P. 334-341. 
6. Clarke's analysis of drugs and poisons in pharmaceuticals, body fluids and postmortem material: 4-th ed. / A.C.Moffat, M.D.Osselton, B.Widdop et al. - London, Chicago: Pharmaceutical Press, 2011. - 2736 p.

7. Dallet P., Labat L., Richard M. et al.//J. Liq. Chromatogr. Relat. Technol. - 2002. - Vol. 25 (1). - P. 101-111.

8. Fanton L., Bévalot F., Grait H. et al. // J. Forensic Leg. Med. - 2008. - Vol. 15 (6). - P. 388-390.

9. Rop P.P., Sournac M.H., Burle J. et al. // J. Anal. Toxicol. - 2002. - Vol. 26 (2). - P. 123-126.

10. Flanagan R.J. // Hum. Psychopharmacol. - 2008. - Vol. 23 (Suppl. 1). - P. 43-51.

11. SOFT / AAFS Forensic Laboratory Guidelines. - 2006. - 1-24 p.

12. Titier K., Castaing N., Scotto-Gomez E. et al. // Ther. Drug Monit. - 2003. - Vol. 25 (5). - P. 581-587.

\title{
АНАЛІТИЧНА ДІАГНОСТИКА ОТРУЄНЬ МІЛНАЦИПРАНОМ \\ С.В.Баюрка, С.А.Карпушина, В.П.Мороз \\ Національний фармацевтичний університет
}

Ключові слова: хіміко-токсикологічний аналіз; мілнаципран; ізолювання з біологічного матеріалу; ТШХ-скринінг; високоефективна рідинна хроматографія

Розроблено методику ізолювання мілнаципрану хлороформом із зневодненого біологічного матеріалу з наступною екстракційною очисткою за допомогою системи розчинників н-гексан - ацетонітрил, яка дозволила виділити 47士5\% антидепресанта. Розроблено методику ТШХ-скринінгу ряду антидепресантів з використанням чотирьох рухомих фаз з низькою кореляцією та послідовною схемою візуалізації за допомогою набору хромогенних реактивів, яка дозволяла розділити мілнаципран, венлафаксин, амітриптилін, флуоксетин та сертралін. Якдиференціюючі реагенти нами запропоновано використання реактиву Лібермана та реактиву Манделіна у модибікації, яка полягала у послідовній обробці проби реактивом Манделіна та парою формальдегіду. Розроблені методики ідентифікації та кількісного визначення мілнаципрану в біологічному матеріалі після ТШХ-очистки методом ВЕРХ з мультихвильовим УФ-спектрофотометричним детектуванням. Калібрувальний графік залежності площі піку від концентрації описувався рівнянням: $Y=5,14 \cdot 10^{-5} X$; діапазон лінійності - 24,2-500 мкг/мл; LOD ma LOQ становили, відповідно, 8,0 та 24,2 мкг/мл (при 262 нм). Отримані результати можуть бути використані в судовій токсикології для аналітичної діагностики отруєнь мілнаципраном.

\section{АНАЛИТИЧЕСКАЯ ДИАГНОСТИКА ОТРАВЛЕНИЙ МИЛНАЦИПРАНОМ С.В.Баюрка, С.А.Карпушина, В.П.Мороз Национальный фармацевтический университет}

Ключевые слова: химико-токсикологический анализ; милнаципран; изолирование из биологического материала; ТСХ-скрининг; высокоэффективная жидкостная хроматография

\begin{abstract}
Разработана методика изолирования милнаципрана хлороформом из обезвоженного биологического материала с последующей экстракционной очисткой с помощью системы растворителей н-гексан-ацетонитрил, которая

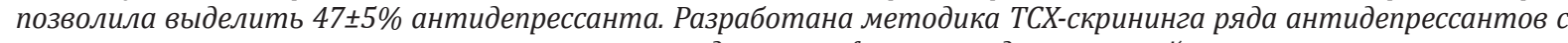
использованием четырех низкокоррелирующих подвижных фаз и последовательной схемы визуализации с помощью набора хромогенных реактивов, которая позволила разделить милнаципран, венлафаксин, амитриптилин, флуоксетин и сертралин. В качестве дифференцирующих реагентов нами предложено использование реактива Либермана и реактива Манделина в модификации, которая заключалась в последовательной обработке пробы реактивом Манделина и парами формальдегида. Разработаны методики идентификации и количественного определения милнаципрана в биологическом материале после ТСХ-очистки методом ВЭЖХ с мультиволновым УФ-спектрофотометрическим детектированием. Калибровочный график зависимости площади пика от концентрации описывался уравнением $Y=5,14 \cdot 10^{-5} X ;$ диапазон линейности -24,2-500 мкг/мл; LOD и LOQ составляли, соответственно, 8,0 и 24,2 мкг/мл (при 262 нм). Полученные результаты могут быть использованы в судебной токсикологии для аналитической диагностики отравлений милнаципраном.
\end{abstract}

Address for correspondence:

Received in 04.03.2016

4, Valentynivska str., Kharkiv, 61168, Ukraine.

Tel. (572) 67-91-92. E-mail: svitkrp@gmail.com.

National University of Pharmacy 